\title{
EKSPLORASI METODE STUDENT TEAMS ACHIEVEMENT \\ DIVISIONS MELAULUI MEDIA AUDIO VISUAL DALAM \\ MENINGKATKAN MOTIVASI, MINAT DAN HASIL BELAJAR IPA KELAS VI SDN ANYELIR 1 KOTA DEPOK
}

\author{
Kustiyono \\ NIM. 836366759 \\ kustiyonoessa@gmail.com
}

\begin{abstract}
ABSTRAK
Penelitan bertujuan untuk Meningkatkan Prestasi Belajar Peserta Didik Kelas VI Sekolah Dasar Negeri Anyelir 1 Kota Depok Pada Mata Pelajaran Ilmu Pengetahuan Alam (IPA) Tema Ciri-ciri khusus makhluk hidupi Metode Student Achievement Teams Divisions (STAD) dan Media Audio Visual. Penelitian Tindakan Kelas dilaksanakan di SDN Anyelir 1 Kecamatan Pancoranmas, Kota Depok dengan jumlah 30 orang peserta didik kelas IV. Dengan penerapan student achievement teams divisions (STAD) dan alat peraga audio visual telah memberikan pengaruh yang sangat baik dengan meningkatkan prestasi belajar dan motivasi peserta didik materi yang disampaikan dimengerti peserta didik, Tanggung jawab peserta didik terhadap tugas tinggi, serta membantu peserta didik untuk terlibat aktif di dalam kelas
\end{abstract}

Kata kunci : Prestasi Belajar IPA, Metode Student Achievement Teams Divisions (STAD) dan Media Audio Visual

\section{BAB I \\ PENDAHULUAN}

\section{A. Latar Belakang Masalah}

Seorang guru yang profesional harus memiliki dasar pengetahuan dan menguasai konsep tentang apa yang akan diberikan, mengetahui dan menyadari dengan mantap materi yang akan diajarkan yang berarti bahwa guru sudah menentukan pokok bahasan apa yang akan diajarkan, metode apa yang akan dipakai serta media yang akan digunakan. Bagaimanapun baiknya program pendidikan dan pengajaran yang disebut kurikulum, bila tidak 
disertai dengan proses belajar mengajar yang baik dan usaha-usaha guru untuk mencapai tujuan tersebut maka tidaklah mungkin pendidikan dan pengajaran itu akan mencapai tujuan yang diharapkan. Untuk mencapai tujuan pembelajaran ini maka peserta didik harus menguasai materi pembelajaran dengan baik, sehingga diharapkan dapat memperoleh nilai sesuai KKM (Kriteria Ketuntasan Minimum) yang telah ditentukan.

Dalam usaha mencapai nilai yang sesuai dengan KKM, guru maupun peserta didik harus melakukan kegiatan pembelajaran dengan baik. Keberhasilan dalam mencapai nilai sesuai KKM merupakan harapan dari semua guru. Ketercapaian KKM ataupun keberhasilan proses pembelajaran bergantung pada peran serta atau partisipasi peserta didik di dalam proses pembelajaran dan peran serta dari guru sebagai fasilitator dalam proses pembelajaran.

Selama ini banyak peserta didik yang menganggap Ilmu Pengetahuan Alam adalah ilmu yang mudah dipelajari oleh peserta didik kelas VI SDN Anyelir 1 Kota Depok, namun pada kenyataannya dari tahun ke tahun tidak ada seorangpun peserta didik yang dapat mencapai nilai sempurna yaitu 10 pada Ujian Sekolah (US). Hal ini membuktikan bahwa nilai prestasi yang diperoleh peserta didik masih jauh dari harapan, ini semua kemungkinan disebabkan pemikiran siswa yang masih meremehkan dalam mempelajari Ilmu Pengetahuan Alam. Selain itu pemahaman anak usia sekolah dasar yang masih berada pada tahap Kognitif (pengetahuan) mengakibatkan sebagian besar peserta didik kelas VI SDN Anyelir 1 Depok kurang aktif dan tidak mampu berfikir kritis dalam pelajaran Ilmu Pengetahuan Alam khususnya materi tentang ciri - ciri khusus makhluk hidup. Hal ini terbukti dengan belum tercapainya Kriteria Ketuntasan Minimum (KKM) yang harus dicapainya yaitu 75

Pada pembelajaran prasiklus didapat nilai rerata kelas 66,2. Peserta didik yang tuntas dalam belajar hanya berjumlah 8 orang dari 30 peserta didik atau 26\% dan yang belum mencapai ketuntasan belajar sebanyak 22 orang dari 30 peserta didik atau $74 \%$. Sedangkan hasil pengamatan menunjukkan 
bahwa sebanyak 13 orang dari 30 peserta didik menjawab dengan benar atau sebesar $43 \%$, dan yang belum menjawab dengan benar sebanyak 17 orang dari 30 peserta didik atau dengan kata lain $57 \%$.

Untuk memperbaiki pembelajaran dan meningkatkan pencapaian hasil yang diharapkan, peneliti merasa perlu melakukan Penelitian Tindakan Kelas (PTK). Dengan merefleksi bersama antar guru maka akan teridentifikasi akar permasalahan. Proses pembelajaran yang selama ini hanya didominasi guru, ,monoton dan hanya menggunakan metode ceramah diubah menjadi pembelajaran yang menyenangkan bagi peserta didik

Dalam penelitian ini akan diupayakan peningkatan pemahaman peserta didik melalui beberapa siklus yang setiap siklusnya melalui beberapa langkah yaitu mulai dari perencanaan, pelaksanaan, pengamatan atau observasi dan refleksi pembelajaran. Pembelajaran yang menyenangkan dapat dilakukan dengan berbagai model dan penggunaan media pembelajaran yang bervariasi. Akan lebih menyenangkan bila didukung oleh seorang guru yang aktif dan berkompeten. Strategi pembelajaran yang digunakan guru yang aktif itu senantiasa disesuaikan dengan materi pelajaran, proses pembelajaran serta situasi, dan kondisinya, tidak monoton, sehingga tujuan dan hasil pembelajaran dapat dicapai dengan baik.

Berdasarkan uraian di atas, peneliti tertarik untuk melakukan PTK mengenai “ "Upaya Meningkatkan Hasil Belajar Peserta Didik Kelas VI Sekolah Dasar Negeri Anyelir 1 Kota Depok Pada Mata Pelajaran Ilmu Pengetahuan Alam (IPA) Tema Ciri - Ciri Khusus Makhluk Hidup Melalui Metode Student Team- Achievement Devisions (STAD) dan Media Audio Visual.

\section{Identifikasi Masalah}

Dari hasil observasi dan diskusi dengan teman sejawat maka masalah pada Penelitian Tindakan Kelas ini dapat diidentifikasikan sebagai berikut: 
a. Rendahnya nilai prestasi belajar Peserta didik yang rerata dibawah KKM

b. Motivasi peserta didik untuk mempelajari materi tentang ciri-ciri khusus makhluk hidup masih kurang.

c. Peserta didik terlihat pasif dan kurang tertarik mempelajari IPA dengan materi ciri-ciri khusus makhluk hidup.

d. Dalam kegiatan belajar mengajar peran guru terlalu dominan sehingga tidak melibatkan peserta didik secara aktif dalam pembelajaran.

e. Keberanian peserta didik untuk mengajukan pertanyaan, pendapat dan menjawab pertanyaan guru masih rendah.

\section{Analisa Masalah}

Dari identifikasi masalah, penulis berusaha menganalisa serta merumuskan masalah yang terjadi. Adapun analisa masalah yang ditemukan dalam pembelajaran IPA adalah:

a. Guru belum menyampaikan tujuan dan manfaat mempelajari pelajaran IPA dengan materi ciri-ciri khusus makhluk hidup.

b. Guru dalam kegiatan belajar mengajar masih kurang memberikan motivasi kepada peserta didik .

c. Guru tidak menggunakan metode dan media pembelajaran yang tepat dan menarik sehingga peserta didik tidak termotivasi untuk mempelajari materi pembelajaran.

d. Peran guru terlalu dominan dalam kegiatan belajar megajar sehingga tidak melibatkan peserta secara aktif dalam proses pembelajaran.

e. Guru belum memberikan kesempatan seluas-luasnya kepada peserta didik untuk mengemukakan pendapat dan mengajukan pertanyaan dalam kegiatan pembelajaran.

f. Hanya beberapa peserta didik yang aktif di dalam kegiatan pembelajaran .

\section{Alternatif dan Prioritas Pemecahan Masalah}

Dari analisis masalah di atas, penulis menemukan alternatif dan prioritas pemecahan masalah sebagai berikut : 
a. Guru dalam kegiatan awal pembelajaran sebaiknya menyampaikan tujuan dan manfaat mempelajari materi pembalajaran.

b. Guru dalam kegiatan pembelajaran harus memberikan motivasi dan reward kepada peserta didik agar memiliki motivasi yang tinggi dalam pembelajaran.

c. Dalam penyampaian pembelajaran guru harus menggunakan metode dan media yang menarik, tepat, mudah difahami serta memadai agar pembelajaran jadi menyenangkan.

d. Peran guru dalam pembelajaran sebaiknya tidak terlalu dominan sehingga lebih banyak melibatkan peserta didik secara aktif dalam pembelajaran

e. Guru sebaiknya memberikan kesempatan yang seluas-luasnya kepada peserta didik untuk menyampaikan pertanyaan, ide dan pendapat dalam proses kegiatan belajar.

f. Guru sebaiknya memberikan reward kepada semua peserta didik yang berhasil menjawab pertanyaan guru agar dapat memotivasi semua siswa sehingga tidak hanya beberapa siswa saja yang aktif dalam pembelajaran.

Maka apabila dalam proses kegiatan belajar mengajar khususnya penggunaan metode dan media pembelajaran yang kurang tepat dapat mempengaruhi hasil belajar peserta didik, dalam penelitian tindakan kelas ini, penulis mencoba meneliti tentang metode Student Teams Achievement Devisions (STAD) dan media Audio Visual untuk meningkatkan pemahaman peserta didik pada mata pelajaran IPA tentang Ciri-Ciri Khusus Makhluk Hidup

\section{B. Rumusan Masalah}

Berdasarkan latar belakang masalah di atas, maka penulis yang juga guru di kelas VI merumuskan masalah sebagai berikut : "Bagaimana meningkatkan prestasi belajar peserta didik kelas VI Sekolah Dasar Negeri 
Anyelir 1 Kota Depok pada mata pelajaran Ilmu Pengetahuan Alam (IPA) tema Ciri - ciri khusus makhluk hidup melalui metode Student TeamsAchievement Devisions (STAD) dan media audio visual

\section{Tujuan Penelitian Perbaikan Pembelajaran}

Tujuan utama PTK ini adalah Upaya Meningkatkan Prestasi Belajar Peserta Didik Kelas VI Sekolah Dasar Negeri Anyelir 1 Kota Depok Pada Mata Pelajaran Ilmu Pengetahuan Alam (IPA) Tema Ciri-Ciri Khusus Makhluk Hidup Melalui Metode Student Teams - Achievement Devisions (STAD) Dan Media Audio Visual

Tujuan ini dapat diperinci sebagai berikut :

\section{Manfaat hasil Penelitian}

Adapun manfaat dalam penelitian tindakan kelas (action research) ini adalah:

\section{Peserta didik :}

a. Peserta didik menjadi lebih aktif dan kreatif dalam belajar Ilmu Pengetahuan Alam (IPA).

b. Motivasi untuk meningkatkan pemahaman mata pelajaran Ilmu Pengetahuan Alam (IPA) pada peserta didik bertambah.

c. Menciptakan pembelajaran yang menyenangkan pada mata pelajaran Ilmu Pengetahuan Alam (IPA) sehingga peserta didik akan lebih mudah dalam memahami materi pembelajaran dan anak tidak bosan selama pelajaran berlangsung.

d. Dapat meningkatkan prestasi belajar peserta didik

\section{Bagi guru}

a. Memperbaiki proses belajar mengajar dalam pelajaran IPA di sekolah dasar.

b. Mengembangkan kualitas guru dalam mengajarkan Ilmu Pengetahuan Alam (IPA) di sekolah dasar.

c. Memberikan alterntif kegiatan pembelajaran Ilmu Pengetahuan Alam (IPA). 
d. Menambah wawasan guru dengan menerapkan metode-metode baru di dalam pembelajaran IPA.

\section{Bagi Sekolah}

a. Meningkatkan Mutu pendidikan di sekolah

b. Memaksimalkan Peranan dan tanggung jawab sekolah dalam membekali peserta didiknya dengan pengetahuan dan kemampuan dasar Ilmu Pengetahuan Alam

\section{Manfaat hasil Penelitian}

a. Sebagai pengalaman berharga bagi peneliti dalam mengaplikasikan ilmu pengetahuan sehingga akan memperkaya khasanah pengetahuan penelitian untuk diamalkan.

b. Sebagai bahan acuan untuk peneliti agar menjadi lebih baik pada saat melakukan pembelajaran

\section{BAB II}

\section{KAJIAN PUSTAKA}

\section{A. Prestasi Belajar IPA}

\section{Pengertian Prestasi Belajar}

Prestasi belajar adalah sebuah kalimat yang terdiri dari dua kata, yakni "prestasi” dan " belajar". Antara kata " prestasi” dan " belajar" mempunyai arti yang berbeda. Menurut WJS. Poerwadarminta (1986 : 78) berpendapat bahwa prestasi adalah hasil yang telah dicapai (dilakukan, dikerjakan, dan sebagainya).

Sedangkan menurut Mas'ud Khasan Abdul Qohar (1994 : 28) prestasi adalah apa yang telah dapat diciptakan, hasil pekerjaan, hasil yang menyenangkan hati yang diperoleh dengan jalan keuletan kerja. Untuk mengetahui keberhasilan yang telah dicapai dalam suatu proses belajar mengajar menurut taksonomi Bloom ada 3 ranah yang meliputi aspek yaitu : 
a) Kognitif yang ditandai dengan kemampuan berfikir dalam memperkaya pengetahuannya.

b) Afektif dengan dilandasi nilai-nilai dan sikap mental siswa akan timbul kesadaran dan kemampuannya untuk mempraktekkan segala sesuatu yang telah dipelajari.

c) Psikomotorik yaitu ketrampilan jasmani yang dapat dilihat dan diamati yang menitik beratkan pada kemampuan gerak tubuh seseorang.

Menurut Ngalim Purwanto (1987 : 85-86) Evaluasi belajar merupakan penilaian terhadap pertumbuhan dan kemajuan siswa ke arah tujuan-tujuan yang telah ditetapkan dalam kurikulum. Adapun fungsi peningkatan prestasi belajar menurut Ngalim Poerwanto adalah sebagai berikut :

1. Untuk menyeleksi kenaikan kelas.

2. Untuk menyeleksi kelulusan diakhir program

3. Untuk mengetahui perkembangan dan pertumbuhan siswa.

4. Untuk meningkatkan efektifitas dan efisiensi pengajaran

Menurut S.Nasution (1982 : 38-39), tujuan penilaian dalam proses proses belajar mengajar adalah merupakan pengambilan keputusan tentang hasil belajar dan pemahaman tentang peserta didik serta perbaikan dan pengembangan tentang peserta didik. Pengambilan keputusan merupakan suatu keharusan bagi guru dalam mengetahui berhasil tidaknya siswa dalam proses belajar mengajar. Pemahaman tentang peserta didik untuk mengetahui sejauh mana anak didik mengerti apa yang disampaikan guru pada waktu proses belajar mengajar berlangsung dan sejauh mana guru memberikan perbaikan dan pengayaan kepada siswa dalam proses belajar tersebut.

Tujuan peningkatan prestasi belajar menurut Ngalim Poerwanto adalah merupakan dan sebagai bukti tingkat kemampuan dan keberhasilan siswa dalam pencapaian tujuan kurikuler. Tujuan peningkatan prestasi belajar dapat dilihat dari data hasil tes sub sumatif siswa. Tes sub sumatif ini merupakan tes untuk mengukur kemampuan 
dan keberhasilan ada tidaknya prestasi setelah mengikuti kegiatan belajar mengajar setiap pokok bahasan.

Fungsi dan tujuan peningkatan prestasi belajar merupakan langkah untuk mempersiapkan siswa berhasil tidaknya siswa dalam proses belajar mengajar, sehingga guru dapat menentukan kelulusan diakhir program pengajaran maupun kenaikan kelas. Setelah kita mengetahui fungsi dan tujuan peningkati dan kedudukan pentingnya prestasi belajar.

Dari beberapa pengertian prestasi belajar yang dikemukakan para ahli di atas, dapat ditarik kesimpulan bahwa prestasi belajar adalah hasil yang diperoleh berupa kesan-kesan yang mengakibatkan perubahan dalam diri individu sebagai hasil dari aktivitas dalam belajar.

Belajar merupakan keharusan bagi manusia sebagai makhluk sosial yang selalu mengadakan interaksi dengan sesamanya untuk menambah pengetahuan. Sebaliknya, tak ada makhluk selain manusia yang setelah dewasa mampu menciptakan apa yang telah diciptakan oleh manusia dewasa, kesemuanya dapat diperoleh karena manusia belajar. Jelaslah kiranya, bahwa belajar sangat penting bagi manusia dalam kehidupan bermasyarakat. Dalam kehidupan manusia, belajar adalah proses yang menimbulkan terjadinya perubahan atau pembaharuan dalam tingkah laku dan kecakapan.

Menurut Rohman Natawidjaya (1979 : 7) belajar adalah suatu proses perubahan tingkah laku yang terjadi pada diri seseorang. Perubahan-perubahan ini meliputi ketrampilan, kebiasaan, pengertian atau apresiasi. Belajar adalah setiap perubahan dalam tingkah laku yang terjadi sebagai suatu hasil dari latihan atau pengalaman.

Menurut pendapat Nasution belajar itu sangat komplek tampak dari batasan-batasan belajar adalah :

a. Belajar adalah perubahan-perubahan dalam sistem urat syaraf.

b. Belajar adalah penambahan pengetahuan

c. Belajar sebagai perubahan kelakuan berkat pengalaman dan latihan.

d. Belajar adalah perubahan tingkah laku, proses pendewasaan dan 
serangkaian kegiatan yang merupakan hasil dari pengalaman.

Setiap manusia akan mengalami banyak perkembangan dan perubahan di berbagai bidang kehidupan, perkembangan ini dimungkinkan karena adanya kemampuan manusia untuk berupaya dan belajar, yaitu dengan menjalani berbagai perubahan dari lahir hingga lanjut usia. Belajar merupakan proses perubahan tingkah laku yang ditimbulkan atau diubah melalui praktek dan latihan.

Berdasarkan pada definisi-definisi belajar tersebut, bahwa pengertian belajar adalah suatu proses yang menuju pada perubahan atau perbaikan tingkah laku tersebut antara lain meliputi kebiasaan, kecakapan, ketrampilan sikap, dan kepandaian individu ke arah yang lebih baik dari sebelumnya.

Setiap individu yang belajar pasti mengalami perubahanperubahan. Prestasi adalah sesuatu yang telah dicapai atau dilakukan. Menurut Winkel (1989 : 1), suatu bukti dari keberhasilan usaha yang dicapai adalah prestasi. Prestasi adalah keberhasilan yang dicapai individu dalam proses belajar yang terlihat dalam perubahan tingkah laku yang pada dasarnya merupakan kesatuan.

Setiap orang mengharapkan bahwa dari setiap kegiatan yang dilakukannya dapat menghasilkan suatu prestasi. Prestasi merupakan penilaian terhadap sesuatu yang digunakan untuk menilai hasil-hasil pengajaran yang diberikan guru pada peserta didiknya dalam waktu tertentu.

Prestasi belajar bagi seorang siswa sangat penting, karena prestasi belajar merupakan suatu gambaran tingkat keberhasilan dari proses belajar dalam kurun waktu tertentu. Untuk mengetahui prestasi belajar siswa digunakan evaluasi, dimana siswa dituntut untuk memberikan prestasi tertentu dan dari prestasi itu akan diketahui apakah hasil belajar yang dicapai sudah sesuai yang diharapkan.

Setiap individu setelah mengalami proses belajar akan mengetahui hasil belajar yang diperolehnya. Hasil belajar ini perlu diukur untuk 
mengetahui target yang dicapai selama proses belajar mengajar berlangsung. Hasil belajar dapat digolongkan menjadi empat kelompok, yaitu :

a. Pengetahuan : seperti fakta, gagasan, kaidah dan konsep.

b. Kemampuan : yaitu kemampuan menganalisa, menerangkan, memproduksi dan membuat generalisasi.

c. Kebiasaan dan ketrampilan dalam bentuk perilaku

d. Sikap berbentuk apresiasi ataupun minat.

Tiap-tiap individu yang belajar tentu akan memperoleh hasil belajar yang berbeda antara satu dengan yang lainnya. Karena masingmasing individu memiliki potensi yang berbeda beda antara satu dengan lainnya, yang menyebabkan ada peserta didik memperoleh prestasi belajar tinggi, adapula peserta didik yang memiliki prestasi belajar yang rendah. Banyak faktor yang dapat mempengaruhi keberhasilan belajar peserta didik yaitu faktor yang berasal dari dalam diri siswa atau faktor internal dan yang kedua faktor yang berasal dari luar diri siswa atau faktor eksternal.

Adapun faktor yang berasal dari dalam diri peserta didik meliputi

faktor kematangan/pertumbuhan, kecerdasan, motivasi, minat dan perhatian. Sedangkan faktor yang berasal dari luar diri peserta didik antara lain faktor keluarga/keadaan rumah tangga, guru dan cara mengajarnya, alat-alat yang dipergunakan dalam belajar mengajar, kesempatan yang tersedia, lingkungan sekolah dan lingkungan masyarakat.

Untuk mendapatkan prestasi belajar yang diinginkan, semua faktor tersebut saling menunjang. Faktor kecerdasan saja belum dapat menjamin keberhasilan peserta didik dalam proses belajar, karena faktor lingkungan keluarga seperti kondisi ekonominya merupakan salah satu faktor eksternal yang di duga dapat memiliki pengaruh terhadap 
keberhasilan belajar anak di sekolah.

\section{Hakekat pembelajaran IPA.}

Pengertian IPA menurut HW.Fowler et al dalam Abdullah Aly (2009 : 13 ) adalah ilmu yang sistematis dan dirumuskan, berhubungan dengan gejala-gejala kebendaan dan didasarkan terutama atas pengamatan dan induksi. Ilmu Pengetahuan Alam (IPA) dikenal juga dengan istilah sains. Kata sains berasal dari bahasa latin yaitu scienta yang berarti "saya tahu". Dalam bahasa inggris, kata sains berasal dari kata science yang berarti "pengetahuan”. Science kemudian berkembang menjadi social science yang dalam bahasa Indonesia dikenal dengan Ilmu Pengetahuan Sosial (IPS) dan natural science yang dalam bahasa Indonesia dikenal dengan Ilmu Pengetahuan Alam (IPA)

IPA didefinisikan sebagai sekumpulan pengetahuan tentang objek dan fenomena alam yang diperoleh dari hasil pemikiran dan penyelidikan ilmuwan yang dilakukan dengan ketrampilan bereksperimen dengan menggunakan metode ilmiah. Definisi ini memberi pengertian bahwa IPA merupakan cabang pengetahuan yang dibangun berdasarkan pengamatan dan klasifikasi data, dan biasanya disusun diverifikasi dalam hukum hukum yang bersifat kuantitatif, yang melibatkan aplikasi penalaran matematis dan analisis data terhadap gejala-gejala alam. Dengan demikian pada hakekatnya IPA merupakan ilmu pengetahuan tentang gejala alam yang dituangkan berupa fakta, konsep, prinsip dan hukum yang teruji kebenarannya dan melalui suatu rangkaian kegiatan dalam metode ilmiah.

Adapun pengertian IPA menurut Trowbridge and Bybee (1990) sains atau IPA merupakan representasi dari hubungan dinamis yang mencakup tiga faktor utama yaitu "the exiani body of scientific knowled, the values of science and the method and procecces of science " yang artinya sains merupakan produk dan proses, serta mengandung nilai-nilai. IPA adalah hasil interpretasi tentang dunia kealaman. IPA sebagai 
proses/metode penyelidikan meliputi cara berpikir, sikap dan langkahlangkah kegiatan scientis untuk memperoleh produk-produk IPA, misalnya observasi, pengukuran, merumuskan, menguji hipotesa, mengumpulkan data, bereksperimen dan prediksi.

\section{B. Metode Pembelajaran Tipe Student Team Achievement Division (STAD)}

Metode pembelajaran adalah suatu cara yang dipakai guru untuk menyajikan bahan pelajaran kepada peserta didik dengan cara-cara tertentu untuk mencapai tujuan pengajaran. Model Pembelajaran Koperatif tipe STAD merupakan pendekatan Cooperative Learning yang menekankan pada aktivitas dan interaksi diantara peserta didik untuk saling memotivasi dan saling membantu dalam menguasai meteri pelajaran guna mencapai prestasi yang maksimal.

Pembelajaran kooperatif tipe Student Team Achievement Division (STAD) yang dikembangkan oleh Robert Slavin dan teman-temannya di Universitas John Hopkin (dalam Slavin, 1995) merupakan pembelajaran kooperatif yang paling sederhana, dan merupakan pembelajaran kooperatif yang cocok digunakan oleh guru yang baru mulai menggunakan pembelajaran kooperatif.

Menurut Slavin (2009 : 21) ada lima komponen utama dalam pembelajaran kooperatif metode STAD, yaitu :

a. Penyajian Kelas

Penyajian kelas merupakan penyajian materi yang dilakukan guru secara klasikal dengan menggunakan presentasi verbal atau teks. Penyajian difokuskan pada konsep-konsep dari materi yang dibahas. Setelah penyajian materi, siswa bekerja pada kelompok untuk menuntaskan materi melalui tutorial, kuis atau dikusi.

b. Menetapkan siswa dalam kelompok.

Kelompok menjadi hal yang sangat penting dalam STAD karena di dalam kelompok harus tercipta suatu kerja kooperatif antar siswa 
untuk mencapai kemampuan akademik yang diharapkan. Fungsi dibentuknya kelompok adalah untuk saling meyakinkan bahwa setiap anggota kelompok dapat bekerjasama dalam belajar. Kelompok yang dibentuk sebaiknya terdiri dari satu peserta didik dari kelompok atas, satu peserta didik dari kelompok bawah dan dua peserta didik dari kelompok sedang. Hal ini dilakukan karena guru perlu mempertimbangkan agar jangan sampai terjadi pertentangan antar anggota dalam satu kelompok, namun demikian tidak berarti peserta didik dapat menentukan sendiri teman sekelompoknya.

c. Tes dan kuis

Peserta didik diberi tes individual setelah melaksanakan satu atau dua kali penyajian kelas dan bekerja serta berlatih dalam kelompok. Peserta didik harus menyadari bahwa usaha dan keberhasilan mereka nantinya akan memberikan sumbangan yang sangat berharga bagi kesuksesan kelompok.

d. Skor peningkatan individual.

Skor peningkatan individual berguna untuk memotivasi agar bekerja keras memperoleh hasil yang lebih baik dibandingkan dengan hasil sebelumnya. Skor peningkatan individual dihitung berdasarkan skor dasar dan skor tes. Skor dasar dapat diambil dari skor tes yang paling akhir dimiliki siswa, nilai pretes yang dilakukan oleh guru sebelumnya melaksanakan pembelajaran kooperatif metode STAD.

e. Pengakuan kelompok

Pengakuan kelompok dilakukan dengan memberikan penghargaan atas usaha yang telah dilakukan kelompok selama belajar. Kelompok dapat diberi sertifikat atau bentuk penghargaan lainnya jika dapat mencapai kriteria yang telah ditetapkan bersama. Pemberian penghargaan ini tergantung dari kreativitas guru.

Kebaikan dan kelemahan Pembelajaran Kooperatif tipe STAD Pembelajaran dengan menggunakan metode Kooperatif STAD 
mempunyai kelebihan dan kekurangan. Menurut Slavin dalam Hartati

(1997 : 21) kelebihan dan kekurangan metode ini adalah sebagai berikut :

Kelebihannya :

a. Dapat mengembangkan prestasi peserta didik, baik dari hasil tes yang dibuat oleh guru maupun tes yang dibuat oleh team pembuat soal.

b. Peserta didik mempunyai rasa percaya diri yang meningkat

c. Teknik kerjasama dalam pembelajaran memberikan kesan yang mendalam dalam hubungan interpersonal diantara anggota kelompok yang berbeda etnis.

d. Dapat meningkatkan kepekaan dan kesetiakawanan sosial pada diri peserta didik

Kekurangan metode kooperatif tipe STAD yaitu :

a. Dinamika kelompok tidak akan berjalan apabila guru terlena tidak mengingatkan peserta didik untuk senantiasa menggunakan keterampilan-keterampilan kooperatif dalam kelompok.

b. Bila guru tidak memperhatikan jumlah kelompok misalnya kurang dari empat atau tiga, maka seorang anggota kelompok akan cenderung menarik diri dan kurang aktif, sebaliknya apabila anggota kelompok lebih dari lima maka kemungkinan ada peserta didik yang tidak mendapatkan tugas sehingga hanya membonceng dalam penyelesaian tugas.

c. Kerja kelompok tidak akan berjalan efektif apabila ketua kelompok tidak dapat mengatasi konflik-konflik yang timbul.

\section{c.Hakekat Media Audio Visual}

Menurut Sri Anitah W. (2014 : 6.29) Media audio ialah media yang mengandung pesan dalam bentuk auditif (hanya dapat didengar) yang dapat merangsang pikiran, perasaan, perhatian dan kemauan peserta didik untuk mempelajari bahan ajar, Jenis media audio terdiri atas program kaset suara (audio cassette), $\mathrm{CD}$ audio dan program radio. Penggunaan media audio dalam kegiatan 
pembelajaran pada umumnya untuk melatih ketrampilan yang berhubungan dengan aspek-aspek ketrampilan mendengarkan.

Sesuai dengan namanya, media visual adalah media yang hanya dapat dilihat dengan menggunakan indra penglihatan. Media visual ini terdiri atas media yang dapat diproyeksikan ( projected visual) dan media yang tidak dapat diproyeksikan (non projected visual)

1. Media Visual yang diproyeksikan (Projected Visual)

Media ini adalah media yang menggunakan alat proyeksi (projector) sehingga gambar atau tulisan tampak ada layar (screen). Media proyeksi ini bisa berbentuk media proyeksi diam dan media proyeksi gerak. Jenis alat proyeksi yang saat ini bisa digunakan untuk kegiatan pembelajaran diantaranya adalah Opaque Projection, Overhead projection (OHP) dan slide projection. Untuk menampilkan gambar hidup (motion pictures) bisa menggunakan alat proyeksi yang disebut filmstrips atau film projection. Dengan adanya perkembangan jaman dalam dunia media visual saat ini di sekolah- sekolah yang sudah modern sudah digunakan alat proyeksi LCD dengan bantuan komputer.

2. Media Visual Tidak diproyeksikan (Non projected Visual)

Jenis media visual tidak diroyeksikan antara lain :
a. Gambar fotografik
b. Grafis (Graphic)
c. Media tiga dimensi.

Masih menurut Sri Anitah W. (2014 :6.30) Media Audiovisual adalah merupakan kombinasi audio dan visual atau biasa disebut pandang dengar. Sudah barang tentu apabila menggunakan media ini akan semakin lengkap dan optimal penyajian bahan ajar kepada siswa, selain itu media ini dalam batas -batas tertentu dapat juga menggantikan peran dan tugas guru. Dalam hal ini, guru tidak selalu berperan sebagai penyaji materi (teacher), tetapi penyajian materi bisa digantikan oleh media audio visual maka peran guru bisa beralih menjadi fasilitator belajar, yaitu memberikan kemudahan bagi 
para siswa untuk belajar. Contoh dari media audiovisual diantaranya program video/televisi pendidikan, video/televisi instruksional, program slide suara (sound slide) dan program CD Interaktif.

Dalam kehidupan sehari-hari sering kita melihat dan mendengar banyak pihak yang menggunakan berbagai media untuk berbagai keperluan, misalnya dalam menanam sebuah pohon diperlukan suatu media tanam yang cocok agar pohon tersebut dapat tumbuh subur. Media tersebut pada dasarnya adalah sebuah perantara agar tanaman yang kita tanam dapat tumbuh dengan baik.

Dalam dunia pendidikan media juga diperlukan dalam melakukan kegiatan kegiatan belajar mengajar, dengan media seorang guru pada saat menyajikan bahan ajar kepada siswa materi yang disampaikan akan lebih mudah diserap dan diterima oleh peserta didik. Dengan diterima atau diserapnya bahan ajar tersebut terjadi perubahan-perubahan perilaku baik berupa pengetahuan (kognitif), nilai-nilai atau sikap (afektif) maupun keterampilan (psikomotor). Selanjutnya media menurut Heinich (1982) yang dikutip oleh Winataputra (2000 : 5.4) berasal dari bahasa latin merupakan bentuk jamak dari kata "medium" yang secara harfiah berarti "perantara" (between) yaitu perantara sumber pesan (source) dengan penerima pesan (receiver).

Pendapat berikutnya dikemukakan oleh Briggs yang dikutip oleh Sadiman dalam bukunya Media Pendidikan (1996 : 6) bahwa media adalah segala alat fisik yang dapat menyajikan pesan serta merangsang siswa untuk belajar. Pendapat lain disampaikan oleh National Education Association dalam Sadiman (1996 : 6) media adalah sebagai bentuk komunikasi baik tercetak maupun audio-visual dan peralatannya, media dapat dimanipulasi, dilihat didengar atau dibaca.

Berdasarkan uraian para ahli diatas dapat disimpulkan bahwa media pembelajaran adalah penyalur atau perantara pesan-pesan pembelajaran yang disampaikan oleh sumber pesan (guru) kepada penerima pesan (peserta didik) dalam bentuk tercetak, audio-visual dan peralatan dengan maksud agar pesan- 
pesan tersebut dapat diserap cepat dan tepat sesuai dengan tujuan pembelajaran.

Media pembelajaran menurut Winataputra (2000: 5.13) dikelompokan menjadi tiga (1) media visual, yaitu media pembelajaran yang dapat dilihat dengan menggunakan indra penglihatan, (2) media audio adalah media yang mengandung pesan dalam bentuk audif (hanya dapat didengar) yang dapat merangsang, berfikir, perasaan, perhatian dan kemauan siswa, (3) media audio visual, media ini merupakan kombinasi audio dan visual media pandang dengar.

Secara rinci media pembelajaran menurut Winataputra (2000 : 5.4) terdiri dari dua unsur yaitu:

1. Perangkat lunak (software) adalah informasi atau bahan ajar itu sendiri yang akan disampaikan kepada siswa.

2. Perangkat keras (hardware) adalah sarana atau peralatan yang digunakan untuk menyajikan pesan atau bahan ajar tersebut.

Media pembelajaran sering kali dianggap hanya terbatas sebagai alat bantu semata yang boleh diabaikan mana kala media tersebut tidak ada. Tetapi bila kita perhatikan betapa media ini akan memberikan kontribusi atau sumbangan yang sangat besar bagi tercapainya tujuan pembelajaran yang diharapkan.

Menurut Rokhimat (2003 : 5) media pembelajaran mempunyai fungsi untuk meningkatkan kualitas belajar mengajar dan dapat mengurangi verbalisme para siswa, sehingga melalui media pembelajaran guru dapat lebih mengefektifkan pencapaian tujuan pembelajaran. Perencanaan pengadaan kebutuhan media pendidikan didasarkan pada persyaratan dan perhitungan dari segi kualitas dapat dipertanggung jawabkan dan dari segi kuantitas dapat mencukupi kebutuhan sekolah.

Dalam pemilihan media mempertimbangkan ketersediaan media di tempat tersebut bila tidak ada diupayakan dengan cara membuat atau membeli, penyediaan dana, tenaga dan fasilitas lainnya juga harus dipertimbangkan. Efektifitas penggunaan, keluwesan, kepraktisan dan 
keadaan media dalam jangka waktu lama masih dapat digunakan berulangulang. Pemilihan media pembelajaran menurut Situmorang dalam bukunya Pengajaran d xengan Media (1998 : 84) disebutkan ada tiga ranah yang akan dicapai dalam pembelajaran ranah afektif, kognitif dan psikomotor. Setiap ranah dalam pencapaiannya memerlukan strategi yang berbeda, demikian juga dengan media pembelajaran yang digunakan.

Menurut Sumiati (2008 : 160) Aneka ragam media pembelajaran dapat diklasifisikan berdasarkan ciri-ciri tertentu, antara lain :

1. Berdasarkan kemampuan indera, jenis media pembelajaran terdiri atas: yang terdiri dari

2. Media audio, yaitu jenis media pembelajaran yang menggunakan kemampuan indra telinga atau pendengaran ( audio). Jenis media pembelajaran ini menghasilkan pesan berupa bunyi atau suara. Contoh: radio,tape recorder, telepon.

3. Media visual, yaitu jenis media pembelajaran yang menggunakan kemampuan indra mata/penglihatan (visual). Jenis media pembelajaran ini menghasilkan peran berupa bentuk atau rupa yang dapat dilihat. Contoh; gambar, poster, grafik.

4. Media audio visual, yaitu jenis media pembelajaran yang menggunakan kemampuan indra telinga dan indra mata (audio visual) jenis media pembelajaran ini menghasilkan rupa suara dan bentuk atau rupa. Contoh: televisi, film, video.

Dalam kegiatan pembelajaran agar materi pembelajaran dapat diterima dengan baik serta menarik bagi peserta didik, tidak cukup hanya melalui indra pendengaran saja atau melalui metode ceramah saja, tapi juga bisa menggunakan alat peraga yang bisa dinikmati oleh indera penglihatan. Ada banyak macam media yang dapat digunakan dalam pembelajaran, salah satunya adalah LCD Proyektor atau infokus.

Menurut Anitah (2009:6.17) In-focus atau LCD Proyektor termasuk dalam media visual yang diproyeksikan. Media proyeksi ini berbentuk media 
proyeksi diam, misalnya gambar diam (still pictures) dan media proyeksi gerak, misalnya gambar bergerak (motion pictures). Infokus sebagai media pembelajaran di sekolah dasar bertujuan untuk mengenalkan materi secara audio-visual. Infokus telah memberikan dampak yang besar bagi dunia pendidikan. Guru dapat menggunakan infokus sebagai media pembelajaran dengan cara menampilkan materi pelajaran pada layar infokus dengan demikian kegiatan belajar dan mengajar terlihat hidup dan bervariasi.

Dari uraian para ahli diatas maka penulis dapat mengambil kesimpulan bahwa media pembelajaran penyalur atau perantara pesan-pesan pembelajaran yang disampaikan oleh sumber pesan (guru) kepada penerima pesan (peserta didik) dalam bentuk tercetak, audio-visual dan peralatan dengan maksud agar pesan-pesan tersebut dapat diserap cepat dan tepat sesuai dengan tujuan pembelajaran. Media Audio visual yang digunakan penulis adalah dengan menggunakan infokus dengan cara menayangkan film dan gambar mengenai Mengenal Sistem Pemerintahan Tingkat Pusat

\section{BAB III}

\section{PELAKSANAAN PENELITIAN PERBAIKAN PEMBELAJARAN}

A. Subjek, Tempat, Waktu Penelitian dan Pihak yang Membantu

1. Subjek dan Tempat Penelitian

Subjek Penelitian Tindakan Kelas dipilih dan dilaksanakan berdasarkan tempat penulis bertugas, dengan jumlah 30 orang peserta didik kelas VI SDN Anyelir 1, Kecamatan Pancoranmas, Kota Depok. Tempat yang digunakan berlokasi di Nusantara Raya No.241 Kelurahan Depok, Kecamatan Pancoranmas, Kota Depok.

2. Waktu Penelitian

Penelitian tindakan kelas pada pelajaran IPA dilaksanakan mulai dari perencanaan hingga sampai pada laporan hasil penelitian. Adapun waktu penelitian tindakan kelas berlangsung mulai dari tanggal 18 Juli 2019. 
Dalam pelaksanaannya penelitian tindakan kelas diawali dengan prasiklus yang dilaksanakan pada hari Jum'at tanggal 22 Juli 2019 setelah adanya permasalahan yang ditemui dikelas. Kemudian dilanjutkan dengan tahap berikutnya yaitu perbaikan pembelajaran siklus I pada hari Kamis, 28 Juli 2019 yang merupakan perbaikan pembelajaran tahap pertama setelah prasiklus. Tahap berikutnya adalah pelaksanaan siklus II pada hari Selasa tanggal 9 Agustus 2019, yang merupakan perbaikan dari pembelajaran pada tahap siklus I yang hasilnya diharapkan akan lebih baik. Berikut adalah tabel Jadwal Pelaksanaan Perbaikan Pembelajaran pada tahap prasiklus, Siklus 1 dan siklus 2

\section{B. Desain Prosedur Perbaikan Pembelajaran}

Agar memperoleh hasil penelitian yang diharapkan dan kegiatan penelitian ini terarah dengan baik, maka peneliti terlebih dahulu melakukan persiapan penelitian. Persiapan penelitian yang dilakukan meliputi hal-hal sebagai berikut:

1. Guru melakukan observasi tentang hal-hal yang akan diteliti, menyiapkan sarana dan prasarana yang diperlukan.

2. Guru menentukan kelas yang akan diteliti yaitu kelas VI SDN Anyelir 1, Kota Depok

3. Guru menentukan mata pelajaran yang akan dijadikan objek penelitian sesuai dengan masalah yang terjadi di kelas tersebut yaitu pelajaran Ilmu Pengetahuan Alam (IPA) dengan tema Ciri-ciri Khusus Mahluk Hidup.

4. Guru menentukan materi pembelajaran yang akan diteliti yaitu pelajaran IPA dengan tema Ciri-ciri khusus mahkluk hidup.

5. Guru membuat perencanaan penelitian tindakan kelas dengan prosedur pelaksanaan mulai dari perencanaan tindakan, pelaksanaan, observasi, dan evaluasi.

Pelaksanaan perbaikan pembelajaran yang peneliti lakukan melalui prosedur dan beberapa tahapan. Pada setiap siklus terdiri dari beberapa 
tahapan antara lain : tahap persiapan sebagai bagian dari perencanaan, tahap pelaksanaan, tahap pengamatan atau obsesrvasi dan tahap refleksi.

Pada setiap siklus dalam penelitian ini mempunyai langkah dan tahapan yang sama. Guru melakukan prasiklus sebagai langkah untuk mengetahui permasalahan yang menjadi latar belakang penelitian tindakan kelas dari hasil pembelajaran pra siklus kemudian dilanjutkan dengan kegiatan pembelajaran siklus I sebagai cara untuk memperbaiki pelaksanaan dan hasil pembelajaran dari prasiklus . Selanjutnya dari hasil pembelajaran pada siklus I dianalisa dan dievaluasi, apabila hasilnya belum mencapai tujuan yang diharapkan maka dilanjutkan dengan pembelajaran perbaikan pada siklus ke II sebagai perbaikan dari siklus I.

Selanjutnya peneliti melakukan diskusi setelah mempelajari hasil pengamatan yang dilakukan oleh teman sejawat kemudian peneliti mempersiapkan segala sesuatu yang diperlukan dalam pelaksanaan perbaikan pembelajaran sebagai langkah dalam penelitian

Dalam pelaksanaanya penelitian dilakukan dalam dua siklus yang masing-masing melalui 4 tahapan yaitu tahap perencanaan, pelaksanaan, pengamatan dan refleksi. Adapun pelaksanaan penelitian tersebut dideskripsikan sebagai berikut:

\section{Siklus 1}

\section{a. Persiapan}

1. Pelaksanaan pembelajaran yang akan dilaksanakan direncanakan pada hari, Kamis tanggal 28 Juli 2019.

2. Sebagai persiapan dalam pembelajaran guru menyusun Rencana Perbaikan Pembelajaran untuk mata pelajaran Ilmu Pengetahuan Alam (IPA) dengan tema Ciri-ciri Khusus Makhluk Hidup

3. Untuk menunjang keberhasilan dalam pembelajaran guru menambahkan metode pembelajaran yang semula hanya menggunakan metode ceramah dan tanya jawab ditambah dengan 
metode diskusi dan pemberian tugas dengan harapan peserta didik akan lebih aktif di dalam pembelajaran.

4. Guru mempersiapkan sumber belajar dan bahan ajar serta media pembelajaran berupa gambar beberapa jenis hewan yang memiliki ciri-ciri khusus.

5. Guru mempersiapkan lembar diskusi, lembar kerja kelompok dan lembar penilaian untuk menunjang keberhasilan pembelajaran.

\section{b. Pelaksanaan}

1. 1 , Pendahuluan (5 menit)

Apersepsi dan motivasi

- Guru menyampaikan apersepsi dengan melakukan tanya jawab tentang materi pembelajaran pada pertemuan sebelumnya untuk menggali pemahaman siswa.

- Sebutkan 3 macam hewan yang memiliki ciri khusus ?

- Sebutkan salah satu ciri khusus pada cicak!

- Mengapa cicak tidak jatuh ketika merayap pada dinding ?

- Guru memberikan motivasi tentang pentingnya siswa mempelajari materi pembelajaran pada kegiatan ini.

- Guru menyampaikan tujuan pembelajaran dan komptensi yang diharapkan siswa.

2. Kegiatan inti (20 menit)

- Guru sebelumnya menempelkan gambar tentang makhluk hidup yang mempunyai ciri - ciri khusus pada papan tulis.

- Selanjutnya guru menjelaskan tentang beberapa makhluk hidup yang mempunyai ciri - ciri khusus secara sepintas.

- Peserta didik kemudian diminta maju ke depan untuk menunjukkan beberapa hewan yang memiliki ciri-ciri khusus pada gambar .

- Dengan tanya jawab peserta didik diminta untuk menyebutkan beberapa contoh ciri khusus yang di memiliki oleh hewan yang telah ditunjukkan 
pada gambar.

- Guru selanjutnya membentuk beberapa kelompok diskusi yang terdiri dari 5 orang peserta didik.

- Setelah kelompok diskusi terbentuk.guru menjelaskan langkah-langkah kerja dalam pelaksanaan diskusi.

- Guru kemudian membagikan lembar diskusi pada setiap kelompok . Setelah itu Peserta didik melakukan diskusi kelompok.

- Guru melakukan pengawasan terhadap pelaksanaan diskusi sekaligus mengadakan penilaian terhadap setiap peserta didik untuk menilai sejauh mana keaktifan peserta didik dalam melaksanakan diskusi.

- Selama pelaksanaan diskusi guru selalu melaksanakan pengawasan sambil melayani peserta didik yang memerlukan penjelasan tentang materi yang didiskusikan.

- Setelah selesai pelaksanaan diskusi, setiap kelompok mempresentasikan hasil diskusi dan kelompok lain menanggapi hasil diskusi.

- Guru bersama dengan peserta didik menyimpulkan hasil diskusi kelompok.

- Guru selanjutnya memberikan lembar tugas kepada setiap peserta didik untuk mengidentifikasi ciri-ciri makhluk hidup dan kaitannya dengan lingkungan hidupnya

- $\quad$ Setelah selesai guru bersama-sama peserta didik membahas hasil kerja peserta didik dan memberikan kesimpulan.

- Guru selanjutnya mengadakan tanya jawab untuk mengetahui tingkat pemahaman peserta didik.

\section{Kegiatan Penutup (10 menit)}

- Guru bersama siswa menyimpulkan tentang materi pembelajaran yang baru dipelajari

* Makhluk hidup yang ada disekitar memiliki beberapa ciri khusus.

* Ciri khusus yang dimiliki oleh makhluk hidup digunakan dalam menyesuaikan diri dengan lingkungan tempat hidupnya dan untuk 
mengelabuhi musuhnya.

* Beberapa jenis makhluk hidup yang memiliki ciri khusus adalah kelelawar, cicak, bunglon, unta dan lain-lain.

- Guru melakukan evaluasi untuk mengetahui daya serap siswa tentang materi pelajaran yang baru di pelajari

- Guru melakukan tindak lanjut dengan memberikan tugas dan PR di rumah.

\section{c. Pengamatan}

Setelah guru melaksanakan pembelajaran pada siklus I sebagai upaya untuk perbaikan pra siklus, teman sejawat kemudian melaporkan hasil pengamatannya. Dari hasil pengamatan dapat disimpulkan sebagai berikut :

a) Peserta didik masih kurang termotivasi dalam pembelajaran meskipun guru telah menyampaikan tujuan mempelajari materi tersebut, hal ini terlihat dari beberapa peserta didik yang kurang aktif dalam pembelajaran..

b) Hasil evaluasi yang dilakukan oleh guru menunjukkan bahwa rerata kelas yang diperoleh 71,6 masih dibawah KKM yaitu 75,00 dan hasil pengamatan menunjukkan bahwa sebanyak 12 orang dari 30 peserta didik atau 40\% sudah mencapai KKM sedangkan 18 orang dari 30 peserta didik atau $70 \%$ masih belum mencapai KKM

c) Peserta didik belum mempunyai tanggung jawab yang tinggi hal ini terbukti ketika diberikan tugas belum dikerjakan dengan optimal.

d) Penggunaan media dan alat peraga yang digunakan oleh guru belum maksimal

e) Keterlibatan peserta didik dalam proses pembelajaran masih kurang sehingga peserta didik belum semua aktif dalam kegiatan belajar.. 


\section{d. Refleksi}

Setelah selesai melaksanakan pembelajaran pada siklus I, peneliti bersama teman sejawat melakukan refleksi untuk menganalisa dan menemukan kekuatan dan kelemahan dalam tindakan perbaikan pembelajaran. Hasilnya analisanya adalah sebagai berikut :

1. Kekuatan

a) Dengan menggunakan metode diskusi dan pemberian tugas pembelajaran lebih efektif, peserta didik terlihat lebih aktif.

b) Guru sudah melibatkan peserta didik dalam kegiatan pembelajaran.

c) Guru dalam kegiatan pembelajaran sudah menggunakan media dan alat peraga sehungga peserta didik sudah mulai antusias dalam mengikuti kegiatan belajar, karena pembelajaran tidak monoton.

d) Pemahaman materi yang diperoleh peserta didik sedikit lebih baik karena guru sudah menggunakan media pembelajaran

2. Kelemahan

a) Ketika kegiatan diskusi sedang berlangsung dalam kegiatan belajar mengajar guru masih kurang aktif dalam memandu peserta didik

b) Karena hanya beberapa peserta didik yang aktif, maka pembelajaran seolah-olah didominasi oleh anak yang aktif saja, belum semua melibatkan siswa dalam pembelajaran.

c) Keadaan kelas kurang kondusif karena masih ada beberapa peserta didik yang mengobrol dan bercanda dengan temannya.

d) Tugas yang diberikan oleh guru belum semua peserta didik dapat memamahaminya.

e) Keberanian peserta didik untuk mengajukan pertanyaan tentang materi pelajaran masih kurang.

f) Perolehan hasil rerata kelas masih dibawah KKM yaitu diperoleh nilai rata-rata 71,6. Peserta didik yang sudah 
mencapai $\mathrm{KKM}$ ada 12 orang dari 30 peserta didik atau $40 \%$ dan yang belum mencapai KKM ada 18 orang dari 30 peserta didik atau $60 \%$. Sedangkan hasil pengamatan menunjukkan bahwa sebanyak 14 orang dari 30 peserta didik atau $46 \%$ dapat menjawab pertanyaan guru dengan benar, sedangkan 16 orang dari 30 peserta didik atau $54 \%$ belum dapat menjawab pertanyaan guru dengan benar. Dari hasil yang dicapai pada siklus 1 ternyata masih belum mencapai target yang diharapkan maka peneliti perlu untuk melanjutkan ke siklus berikutnya yaitu siklus II.

\section{Siklus 2}

\section{a. Persiapan}

1. Perencanaan pelaksanaan pembelajaran yang akan dilaksanakan pada hari, Selasa tanggal 9 Agustus 2019.

2. Guru kembali menyusun Rencana Pembelajaran Perbaikan Ilmu Pengetahuan Alam (IPA) dengan tema Ciri-ciri khusus makhluk hidup

3. Untuk mencapai keberhasilan dalam pembelajaran guru mencoba beberapa metode berupa metode ceramah, tanya jawab, diskusi, pemberian tugas dan metode Student Teams-Achievement Division (STAD)

4. Untuk menunjang keberhasilan pembelajaran guru mempersiapkan sumber belajar, bahan ajar dan media pembelajaran berupa LCD, Proyektor untuk menayangkan film pendek tentang ciri - ciri khusus mahkluk hidup.

5. Guru juga menyusun lembar kerja siswa, lembar diskusi dan lembar kuis serta alat evaluasi untuk mengukur keberhasilan dalam pembelajaran. 


\section{b. Pelaksanaan}

1. Pendahuluan (5 menit)

Apersepsi dan motivasi

- Guru menyampaikan apersepsi dengan melakukan tanya jawab tentang materi pembelajaran pada pertemuan sebelumnya untuk menggali pemahaman siswa.

- Sebutkan 3 macam hewan yang memiliki ciri khusus ?

- Sebutkan salah satu ciri khusus pada cicak !

- Mengapa cicak tidak jatuh ketika merayap pada dinding ?

- Guru memberikan motivasi tentang pentingnya siswa mempelajari materi pembelajaran pada kegiatan ini.

- Guru menyampaikan tujuan pembelajaran dan komptensi yang diharapkan siswa.

2. Kegiatan inti (20 menit)

- $\quad$ Guru sebelumnya memutarkan film pendek tentang ciri-ciri khusus beberapa makhluk hidup yang ada di sekitar kita

- Peserta didik menonton film tersebut dan memperhatikan dengan seksama tayangan film tersebut.

- $\quad$ Setelah tayangan film selesai guru menjelaskan secara singkat tentang beberapa jenis makluk hidup yang memiliki ciri-ciri khusus pada tayangan film tersebut.

- Dengan tanya jawab peserta didik diminta untuk menyebutkan beberapa contoh ciri khusus yang di memiliki oleh hewan yang telah ditunjukkan pada gambar.

- Guru selanjutnya membentuk beberapa kelompok kerja yang terdiri dari 5 orang peserta didik.

- Setelah kelompok kerja terbentuk.guru menjelaskan langkah-langkah kerja dalam pelaksanaan kerja kelompok. 
- Guru kemudian membagikan lembar kerja pada setiap kelompok . Setelah itu Peserta didik melakukan kerja kelompok.

- Guru melakukan pengawasan terhadap pelaksanaan kerja kelompok sekaligus mengadakan penilaian terhadap setiap peserta didik untuk menilai sejauh mana keaktifan peserta didik dalam melaksanakan kerja kelompok.

- Selama pelaksanaan kerja kelompok guru selalu melaksanakan pengawasan sambil melayani peserta didik yang memerlukan penjelasan tentang materi yang sedang dikerjakan.

- Peserta didik yang bisa menjawab soal atau menyelesaikan tugas menjelaskan kepada kelompok lainnya sehingga semua anggota dalam kelompok itu mengerti.

- Selanjutnya guru memberikan kuis atau pertanyaan kepada seluruh peserta didik. Pada saat menjawab kuis atau pertanyaan peserta didik tidak boleh saling membantu.

- Guru memberikan penghargaan (rewards) kepada kelompok yang memiliki nilai point

- Penghargaan kelompok didasarkan atas skor yang didapatkan oleh kelompok dan skor kelompok ini dari peningkatan individu dalam setiap kuis

- Guru selanjutnya mengadakan tanya jawab untuk mengetahui tingkat pemahaman peserta didik.

- Selanjutnya guru mengadakan evaluasi.

3. Kegiatan Penutup (10 menit)

- Guru bersama peserta didik menyimpulkan tentang materi pembelajaran yang baru dipelajari

* Makhluk hidup yang ada disekitar memiliki beberapa ciri khusus.

* Ciri khusus yang dimiliki oleh makhluk hidup digunakan dalam menyesuaikan diri dengan lingkungan tempat hidupnya dan untuk mengelabuhi musuhnya. 
* Beberapa jenis makhluk hidup yang memiliki ciri khusus adalah kelelawar, cicak, bunglon, unta dan lain-lain.

- Guru melakukan evaluasi untuk mengetahui daya serap peserta didik tentang

materi pelajaran yang baru dipelajari

Guru melakukan tindak lanjut dengan memberikan tugas dan PR di rumah.

\section{c. Pengamatan}

Setelah guru melaksanakan kegiatan pembelajaran sebagai kelanjutan untuk perbaikan pembelajaran pada siklus I, teman sejawat menyampaikan hasil pengamatannya. Dari hasil pengamatan ternyata bahwa setelah guru menggunakan metode Student Teams Achievement Division (STAD) dan menggunakan media Audio Visual terjadi perubahan yang signifikan. Hal ini dapat terlihat dari hasil belajar yang meningkat dari pra siklus dengan nilai rerata 66,2 kemudian dilanjutkan dengan siklus I dengan nilai rerata 72 dan rerata siklus II adalah 85. Dari peserta didik juga mengalami perubahan yang sangat berbeda karena peserta didik menjadi lebih aktif, antusias, dan memiliki motivasi yang tinggi, sehingga siswa lebih mudah dalam memahami materi pembelajaran dan peningkatan prestasi belajar.

Dari hasil pembelajaran pada siklus ke II, teman sejawat melakukan observasi dan hasilnya dapat disimpulkan bahwa keberhasilan dan peningkatan hasil belajar disebabkan :

a. Dalam kegiatan awal pembelajaran guru sudah menyampaikan tujuan dan manfaat mempelajari materi tentang ciri-ciri khusus makhluk hidup.

b. Dalam kegiatan pembelajaran guru sudah menggunakan metode pembelajaran, teknik pembelajaran yang bervariasi dan efektif serta penggunaan media yang sesuai dengan materi pembelajaran. 
c. Dalam kegiatan belajar mengajar guru sudah memberikan motivasi kepada peserta didik pada saat pembelajaran berlangsung sehingga peserta didik tertarik untuk mempelajari Ilmu Pengetahuan Alam (IPA) dengan tema ciri - ciri khusus makhluk hidup.

d. Dalam kegiatan pembelajaran guru sudah memberikan kesempatan yang seluas -luasnya kepada siswa untuk berperan aktif dalam pembelajaran sehingga suasana belajar tidak membosankan..

e. Selama proses kegiatan belajar mengajar guru sudah memberikan reward dan umpan balik secara langsung kepada peserta didik sehingga peserta didik tampak sangat antusias dalam kegiatan belajar.

\section{d. Refleksi}

Setelah kegiatan perbaikan pembelajaran selesai dilaksanakan guru bersama teman sejawat melakukan refleksi dan mencatat beberapa hal yang sangat berpengaruh dalam penggunaan metode Student Teams - Achievement Division (STAD) dan media audio visual yaitu:

1) Dengan menggunakan metode Student Teams - Achievement Division (STAD) dan alat peraga audio visual guru ingin menciptakan model pembelajaran yang berbeda agar peserta didik mendapatkan suasan baru, sehingga dapat menghindari kebosanan dalam proses pembelajaran.

2) Dengan metode Student Teams - Achievement Division (STAD), dapat membiasakan peserta didik untuk berkomunikasi aktif dalam bertukar fikiran dengan teman. 
3) Metode Student Teams - Achievement Division (STAD) peserta didik diajarkan untuk mandiri, dan memiliki rasa setia kawan yang tinggi.

4) Dengan metode Student Teams - Achievement Division (STAD) Student Teams - Achievement Division (STAD) dan alat peraga audio visual pada perbaikan pembelajaran pada siklus II ini hasil nilai rerata peserta didik sebesar 85 . Peserta didik yang tuntas dalam belajarnya sebanyak 24 dari 30 orang atau $80 \%$. Sedangkan yang belum tuntas sebanyak 6 orang dari 30 peserta didik atau 20\% Dari hasil pengamatan yang belum menjawab dengan benar pertanyaan guru sebanyak 6 orang dari 30 peserta didik atau $20 \%$ sedangkan yang sudah menjawab dengan benar pertanyaan guru sebanyak 24 orang dari 30 peserta didik atau $80 \%$.

5) Dengan Student Teams - Achievement Division (STAD) dan alat peraga audio visual mendapatkan keuntungan, menambah pengalaman dan kepercayaan diri, peserta didik Pada akhirnya kualitas dan hasil belajar semakin membaik, sehingga tidak dilanjutkan dengan siklus berikutnya.

\section{Teknik Analisis Data}

Data yang telah dikumpulkan pada setiap kegiatan observasi dari pelaksanaan siklus penelitian dianalisis secara deskriptif dengan menggunakan teknik presentase untuk melihat kecenderungan yang terjadi dalam kegiatan pembelajaran mata pelajaran IPA.

Dalam pelaksanaan penelitian ini membutuhkan dua siklus perbaikan untuk mata pelajaran IPA. Pada proses perbaikan pembelajaran yang peneliti lakukan adalah melalui tiga tahapan, yaitu diantaranya adalah : perencanaan, pelaksanaan, pengamatan dan refleksi.

Langkah-langkah dalam teknik analisis data yang dilakukan adalah sebagai berikut: 
1. Melaksanakan kegiatan pembelajaran, yang terdiri dari kegiatan prasiklus, siklus 1, dan siklus 2 .

2. Mengumpulkan dan menganalisis nilai evaluasi pembelajaran dari tiap siklus dan mendiskripsikannya

3. Menentukan tingkat keberhasilan dari hasil evaluasi yang ditempuh dalam proses pembelajaran.

4. Tes, yang digunakan untuk mendapatkan data tentang hasil belajar peserta didik.

5. Observasi, yang digunakan untuk mengumpulkan data tentang perkembangan keaktifan peserta didik dalam proses kegiatan belajar mengajar dengan menggunakan metode Student Teams - Achievement Division (STAD).

6. Diskusi dengan teman sejawat tentang keberhasilan dan kekurangan/kelemahan dalam pelaksanaan pembelajaran metode Student Teams - Achievement Division (STAD) dan alat peraga audio visual dan merefleksikan hasil setiap siklus untuk perbaikan-perbaikan aktivitas dan praktek pembelajaran yang akan datang.

\section{BAB IV}

\section{HASIL PERBAIKAN DAN PEMBAHASAN}

\section{A. Deskripsi Hasil Penelitian Perbaikan Pembelajaran}

Supervisor sangat membantu dalam menemukan kelemahan guru dan peserta didik sehingga dapat memberikan masukan terhadap perbaikan pelaksanaan pembelajaran IPA di kelas VI SDN Anyelir 1 Kota Depok Data hasil penelitian Tindakan Kelas kemudian penulis paparkan dalam laporan ini untuk meningkatkan kinerja guru dalam melaksanakan pembelajaran agar lebih baik lagi di masa yang akan datang.

Selanjutnya penulis melaksanakan refleksi setelah melakukan observasi pada proses belajar mengajar untuk menentukan langkah -langkah perbaikan pembelajaran. Setelah dianalisa dari hasil refleksi, ditemukan kekurangan 
peneliti dalam pembelajaran seperti kurang tepatnya metode pembelajaran yang diterapkan serta penggunaan media pembelajaran, sehingga tidak sesuai dengan kebutuhan peserta didik.

Ada beberapa hal yang menjadi perhatian peneliti dan perlu dilakukan perbaikan pada proses pembelajaran berdasarkan hasil refleksi antara lain adalah :

1. Hasil belajar peserta didik pada mata pelajaran IPA masih rendah.

2. Kurangnya perhatian peserta didik dalam pelajaran IPA

3. Materi yang disampaikan guru.kurang menarik sehingga peserta didik tidak termotivasi karena terkesan monoton.

4. Dalam proses pembelajaran.keberanian peserta didik untuk menjawab pertanyaan dari guru belum ada.

Untuk mendapatkan data yang akurat penulis juga membuat beberapa instrumen sebagai berikut :

1. Lembar penilaian siklus 1 dan siklus 2 dengan menuliskan rerata kelas

2. Lembar pengamatan peserta didik yang dapat menjawab pertanyaan atau tidak dapat menjawab pertanyaan guru.

Berikut deskripsi data dari setiap kegiatan pembelajaran prasiklus, siklus 1 , dan siklus 2

\section{Prasiklus}

Pada pembelajaran prasiklus jumlah nilai keseluruhan adalah 1988 dengan rincian nilai tertinggi 91 dan nilai terendah adalah 41, peserta didik yang berhasil mencapai ketuntasan belajar adalah 8 orang dari 30 peserta didik atau 26\% dan yang belum mencapai ketuntasan belajar sebanyak 22 orang dari 30 peserta didik atau $74 \%$. Sedangkan hasil pengamatan menunjukkan bahwa sebanyak 13 orang dari 30 peserta didik menjawab dengan benar atau sebesar $43 \%$, dan yang belum menjawab dengan benar sebanyak 17 orang dari 30 peserta atau $57 \%$ peserta didik. Hal ini tergambar dari tabel 1 dan 2 . Ini menunjukkan bahwa dalam kegiatan 
belajar mengajar guru belum mencapai keberhasilan karena belum mencapai KKM yang diharapkan yaitu 75 .

\section{Siklus 1}

Pada pembelajaran siklus I jumlah nilai keseluruahan adalah 2147 dengan nilai tertinggi yang dicapai peserta didik sebesar 90 dan nilai terendah 40 dengan nilai rerata 71,6. Peserta didik yang mencapai KKM adalah 12 orang dari 30 peserta didik atau $40 \%$ dan peserta didik yang belum mencapai ketuntasan sebanyak 18 atau sebesar $60 \%$. Sedangkan hasil pengamatan menunjukkan bahwa sebanyak 14 orang dari 30 peserta didik menjawab dengan benar atau sebesar $46 \%$, dan yang belum menjawab dengan benar sebanyak 16 orang dari 30 peserta didik atau $54 \%$. Hal ini tergambar pada tabel 3 dan tabel 4

Berikut adalah tabel hasil rata peserta didik dan hasil pengamatan

Dari hasil evaluasi belajar peserta didik yang dilakukan pada siklus I, hasil nilai rerata belum maksimal, karena masih ada nilai peserta didik di bawah KKM sehingga penulis merasa perlu melakukan perbaikan pembelajaran melalui kegiatan siklus II .

Pada siklus II, perolehan jumlah nilai keseluruhan 2536 dengan perolehan nilai tertinggi 100 dan nilai terendah adalah 60. Rerata kelas diperoleh nilai 85 . Peserta didik yang tuntas dalam belajarnya sebanyak 24 orang dari 30 peserta didik atau $80 \%$. Sedang yang belum tuntas sebanyak 6 orang peserta didik atau 20\% Dari hasil pengamatan yang dapat menjawab dengan benar pertanyaan guru sebanyak 24 orang dari 30 peserta didik atau $80 \%$ dan belum menjawab dengan benar pertanyaan guru sebanyak 6 orang dari 30 peserta didik atau 20\% peserta didik. Hal ini dapat dilihat pada tabel 7 dan 8 .

Dengan dilaksanakannya kegiatan siklus 2 yang merupakan perbaikan dari siklus-siklus sebelumnya, kemudian dilakukan evaluasi pembelajaran, ternyata nilai rerata peserta didik yang diperoleh mencapai 85 . 
Setelah dilaksanakan perbaikan, kemudian dilakukan evaluasi pembelajaran, akhirnya dapat disajikan tabel rekapitulasi nilai hasil belajar dan pengamatan. Perbandingan perolehan nilai dari tiap-tiap siklus berbeda. Pada prasiklus nilai tertinggi 91, siklus satu 90, siklus dua 100. Perolehan rerata prasiklus 62 , siklus satu 72 , siklus dua 85 , begitu juga tingkat ketuntasan secara prosentase mengalami peningkatan. Prosentase pada prasiklus $26 \%$, siklus satu $40 \%$, siklus dua $80 \%$

Tabel 6

Data Rekapitulasi Nilai Hasil Belajar IPA

\begin{tabular}{|c|l|c|c|c|c|}
\hline \multirow{2}{*}{ NO } & \multicolumn{2}{|c|}{ NAMA } & \multirow{2}{*}{ L/P } & \multicolumn{3}{|c|}{ NILAI } \\
\cline { 4 - 6 } & & & Prasiklus & Siklus 1 & Siklus 2 \\
\hline 1 & Ahmad Yasin Rantisi Nur F. & L & 62 & 70 & 72 \\
\hline 2 & Aisyah Edwan Mursalat & L & 81 & 82 & 90 \\
\hline 3 & Amanda Nafiza Syamil & P & 71 & 73 & 93 \\
\hline 5 & Ammar Bahy Dafaa & L & 62 & 64 & 88 \\
\hline 6 & Arifina Widhyastuti & P & 70 & 70 & 96 \\
\hline 7 & Baguia Rahma Kusuma & P & 70 & 70 & 90 \\
\hline 8 & Chessta Deva Adabi & L & 50 & 60 & 76 \\
\hline 9 & Dendi Athallah Djuharianto & L & 81 & 90 & 90 \\
\hline 10 & Deru Khairan Djuharianto & L & 61 & 65 & 64 \\
\hline 11 & Dinda Izzati & L & 62 & 65 & 76 \\
\hline 12 & Elang Shiddiq Mahawira & P & 71 & 75 & 92 \\
\hline 13 & & L & 52 & 60 & 93 \\
\hline 14 & Harnum Putri Hardyla & & & & \\
\hline 15 & Khansa Saniyya Adlina & P & 71 & 65 & 76 \\
\hline 16 & Mochammad Althof Syah R. & L & 72 & 72 & 95 \\
\hline 17 & Mohammad Fahri Ilham & L & 52 & 50 & 88 \\
\hline 18 & M. Rafi Gading Saputra & L & 71 & 71 & 76 \\
\hline 19 & Nabila Yasmin & P & 80 & 80 & 95 \\
\hline 20 & Nanda Maulina Ridwan & P & 90 & 90 & 90 \\
\hline 21 & Naquita Nesyhananda & P & 51 & 90 & 95 \\
\hline 22 & Narendro Gupito & L & 51 & 40 & 72 \\
\hline 23 & Naufal Satrya Alchamdany & L & 81 & 90 & 95 \\
\hline 24 & Rafi Dewa Guntara & L & 41 & 60 & 60 \\
\hline 25 & Reviansyah Akbar & 60 & 70 & 89 \\
\hline
\end{tabular}




\begin{tabular}{|c|l|c|c|c|c|}
\hline 26 & Rhevanaira Salwa Rasyad & $\mathrm{P}$ & 52 & 65 & 90 \\
\hline 27 & Shakila Salsabillah & $\mathrm{P}$ & 60 & 60 & 76 \\
\hline 28 & Vihan Rara Agusttina. & $\mathrm{P}$ & 90 & 90 & 92 \\
\hline 29 & Xenaya Humayra Amirudin & $\mathrm{P}$ & 91 & 91 & 100 \\
\hline 30 & Zahwa Khairunnisa. & $\mathrm{P}$ & 50 & 80 & 70 \\
\hline & Jumlah & & 1988 & 2148 & 2536 \\
\hline & Rata Rata & & 66,2 & 72 & 85 \\
\hline & Nilai Terendah & & 41 & 40 & 60 \\
\hline & Nilai Tertinggi & & 91 & 91 & 100 \\
\hline & Ketuntasan & & $26 \%$ & $40 \%$ & $80 \%$ \\
\hline & & & & & \\
\hline
\end{tabular}

Tabel 9

Data Rekapitulasi Pengamatan Hasil Belajar IPA

\begin{tabular}{|c|l|c|c|c|c|c|c|c|}
\hline \multirow{2}{*}{ NO } & \multirow{2}{*}{ NAMA } & \multirow{2}{*}{ L/P } & \multicolumn{2}{c|}{$\begin{array}{c}\text { PRASIKLU } \\
\text { NO S }\end{array}$} & & \multicolumn{2}{|c|}{ SIKLUS 1 } & \multicolumn{2}{|c|}{ SIKLUS 2 } \\
\hline & & & M & TM & M & TM & M & TM \\
\hline 1 & Ahmad Yasin Rantisi Nur F. & L & & $\sqrt{ }$ & & $\sqrt{ }$ & & $\sqrt{ }$ \\
\hline 2 & Aisyah Edwan Mursalat & L & $\sqrt{ }$ & & $\sqrt{ }$ & & $\sqrt{ }$ & \\
\hline 3 & Amanda Nafiza Syamil & P & $\sqrt{ }$ & & $\sqrt{ }$ & & $\sqrt{ }$ & \\
\hline 4 & Ammar Bahy Dafaa & L & & $\sqrt{ }$ & & $\sqrt{ }$ & $\sqrt{ }$ & \\
\hline 5 & Arifina Widhyastuti & P & & $\sqrt{ }$ & $\sqrt{ }$ & & $\sqrt{ }$ & \\
\hline 6 & Aulia Rahma Kusuma & P & & $\sqrt{ }$ & & $\sqrt{ }$ & $\sqrt{ }$ & \\
\hline 7 & Bagus Raja Fathan & L & & $\sqrt{ }$ & & $\sqrt{ }$ & $\sqrt{ }$ & \\
\hline 8 & Chessta Deva Adabi & L & $\sqrt{ }$ & & $\sqrt{ }$ & & $\sqrt{ }$ & \\
\hline 9 & Dendi Athallah Djuharianto & L & & $\sqrt{ }$ & & $\sqrt{ }$ & & $\sqrt{ }$ \\
\hline 10 & Deru Khairan Djuharianto & L & & $\sqrt{ }$ & & $\sqrt{ }$ & $\sqrt{ }$ & \\
\hline 11 & Dinda Izzati & P & $\sqrt{ }$ & & $\sqrt{ }$ & & $\sqrt{ }$ & \\
\hline 12 & Elang Shiddiq Mahawira & L & & $\sqrt{ }$ & & $\sqrt{ }$ & $\sqrt{ }$ & \\
\hline 13 & Hanniyah Kamilah & P & & $\sqrt{ }$ & & $\sqrt{ }$ & & $\sqrt{ }$ \\
\hline 14 & Harnum Putri Hardyla & P & $\sqrt{ }$ & & $\sqrt{ }$ & & $\sqrt{ }$ & \\
\hline 15 & Khansa Saniyya Adlina & P & $\sqrt{ }$ & & & $\sqrt{ }$ & $\sqrt{ }$ & \\
\hline 16 & Mochammad Althof Syah R. & L & $\sqrt{ }$ & & $\sqrt{ }$ & & $\sqrt{ }$ & \\
\hline 17 & Mohammad Fahri Ilham & L & & $\sqrt{ }$ & & $\sqrt{ }$ & $\sqrt{ }$ & \\
\hline 18 & M. Rafi Gading Saputra & L & $\sqrt{ }$ & & $\sqrt{ }$ & & $\sqrt{ }$ & \\
\hline 19 & Nabila Yasmin & P & $\sqrt{ }$ & & $\sqrt{ }$ & & $\sqrt{ }$ & \\
\hline 20 & Nanda Maulina Ridwan & P & $\sqrt{ }$ & & $\sqrt{ }$ & & $\sqrt{ }$ & \\
\hline 21 & Naquita Nesyhananda & P & & $\sqrt{ }$ & & $\sqrt{ }$ & $\sqrt{ }$ & \\
\hline
\end{tabular}




\begin{tabular}{|c|l|c|c|c|c|c|c|c|}
\hline 22 & Narendro Gupito & L & & $\sqrt{ }$ & & $\sqrt{ }$ & & $\sqrt{ }$ \\
\hline 23 & Naufal Satrya Alchamdany & L & $\sqrt{ }$ & & $\sqrt{ }$ & & $\sqrt{ }$ & \\
\hline 24 & Rafi Dewa Guntara & L & & $\sqrt{ }$ & & $\sqrt{ }$ & & $\sqrt{ }$ \\
\hline 25 & Reviansyah Akbar & L & & $\sqrt{ }$ & & $\sqrt{ }$ & $\sqrt{ }$ & \\
\hline 26 & Rhevanaira Salwa Rasyad & P & & $\sqrt{ }$ & & $\sqrt{ }$ & $\sqrt{ }$ & \\
\hline 27 & Shakila Salsabillah & P & & $\sqrt{ }$ & & $\sqrt{ }$ & $\sqrt{ }$ & \\
\hline 28 & Vihan Rara Agusttina. & P & $\sqrt{ }$ & & $\sqrt{ }$ & & $\sqrt{ }$ & \\
\hline 29 & Xenaya Humayra Amirudin & P & $\sqrt{ }$ & & $\sqrt{ }$ & & $\sqrt{ }$ & \\
\hline 30 & Zahwa Khairunnisa. & P & & $\sqrt{ }$ & $\sqrt{ }$ & & & $\sqrt{ }$ \\
\hline \multicolumn{2}{|c}{ JUMLAH } & & 13 & 17 & 14 & 16 & 24 & 6 \\
\hline \multicolumn{2}{|c|}{ PERSENTASE } & & $43 \%$ & $57 \%$ & $46 \%$ & $54 \%$ & $80 \%$ & $20 \%$ \\
\hline
\end{tabular}

\section{B. Pembahasan Hasil Penelitian Perbaikan Pembelajaran}

Pada kegiatan prasiklus dengan menggunakan metode ceramah dan media pembelajaran papan tulis kemudian dievaluasi perolehan nilai rerata peserta didik pada pembelajaran prasiklus jumlah nilai keseluruhan adalah 1988 dengan rincian nilai tertinggi 91 dan nilai terendah adalah 41 dengan nilai rerata kelas 66,2. Peserta didik yang tuntas dalam belajar hanya berjumlah 8 orang dari 30 peserta didik atau $26 \%$ dan yang belum mencapai ketuntasan belajar sebanyak 22 orang dari 30 peserta didik atau $74 \%$. Sedangkan hasil pengamatan menunjukkan bahwa sebanyak 13 orang dari 30 peserta didik menjawab dengan benar atau sebesar $43 \%$, dan yang belum menjawab dengan benar sebanyak 17 orang dari 30 peserta didik atau dengan kata lain $57 \%$.

Pada pembelajaran prasiklus ini nilai rerata pembelajaran IPA di bawah KKM, sehingga pretasi belajar masih rendah. Selanjutnya peserta didik kurang termotivasi dalam pembelajaran, peserta didik menjadi pasif dan tanggung jawab peserta didik terhadap tugas masih rendah. Penyebab faktor tersebut disebababkan karena (1) Guru belum menggunakan media pembelajaran yang sesuai secara maksimal sehingga tidak terciptanya suasana pembelajaran yang kondusif, dan menyenangkan bagi peserta didik. (2) Guru belum menggunakan metode pembelajaran dan teknik pembelajaran yang 
bervariasi dan efektif (3) Guru kurang memberikan motivasi pada saat pembelajaran berlangsung sehingga peserta didik tidak tertarik pada pelajaran IPA. (4) Guru jarang mengadakan umpan balik dan reward secara langsung selama pembelajaran, sehingga peserta didik tidak aktif.

Pada pelaksanaan pembelajaran siklus 1 di SDN Anyelir 1 Kota Depok kelas VI Mata Pelajaran Ilmu Pengetahuan Alam Tema mengenai Ciri -ciri khusus Makhluk Hidup KKM 75 diperoleh jumlah nilai keseluruahan adalah 2148 dengan nilai tertinggi yang dicapai peserta didik sebesar 91 dan nilai terendah 40 dengan nilai rerata 71,6. Peserta didik yang mencapai KKM adalah 12 orang dari 30 peserta didik atau $40 \%$ dan peserta didik yang belum mencapai ketuntasan sebanyak 18 atau sebesar 60\%. Sedangkan hasil pengamatan menunjukkan bahwa sebanyak 14 orang dari 30 peserta didik menjawab dengan benar atau sebesar $46 \%$, dan yang belum menjawab dengan benar sebanyak 16 orang dari 30 peserta didik atau dengan kata lain $54 \%$.

Pada pembelajaran siklus I, penulis menggunakan metode kerja kelompok dan diskusi. Dilihat dari hasil belajar peserta didik, terjadi peningkatan nilai akan tetapi secara rerata masih di bawah KKM.

Dari hasil pengamatan pembelajaran siklus 1, penulis mencatat beberapa masalah yaitu :

1. Peserta didik masih terlihat belum termotivasi dalam belajar

2. Tidak semua peserta didik dalam kelompok terlibat aktif.

3. Guru belum menggunakan media yang sesuai.

4. Media pembelajaran yang digunakan belum yang sesuai secara maksimal sehingga tidak terciptanya suasana pembelajaran yang kondusif, dan menyenangkan bagi peserta didik

5. Kurang memberikan motivasi pada saat pembelajaran berlangsung sehingga peserta didik tidak tertarik pada pelajaran IPA

6. Belum mengadakan reward dan umpan balik secara langsung selama pembelajaran, sehingga peserta didik tidak aktif. 
Dengan demikian maka peneliti melakukan penelitian pada siklus 2 . Untuk mengatasi permasalah di siklus 1 maka peneliti melakukan sebagai berikut :

1. Guru menggunakan media pembelajaran yang sesuai dengan materi pelajaran sehingga menciptakan suasana pembelajaran yang aktif, kreatif dan menyenangkan untuk peserta didik..

2. Guru mengoptimalkan pelaksanan metode diskusi dan kerja kelompok bagi peserta didik pada saat pelaksanan proses belajar mengajar.

3. Dalam penggunaan alat peraga guru lebih bervareasi dan efektif

4. Pada saat pembelajaran berlangsung guru memberikan motivasi kepada peserta didik sehingga dalam mempelajari pelajaran IPA peserta didik lebih tertarik

5. Guru memberikan reward dan umpan balik kepada peserta didik secara langsung selama proses pembelajaran, sehingga peserta didik lebih aktif.

Pada saat perbaikan pembelajaran siklus II, peneliti mencoba memperbaiki kekurang pada saat siklus 1 dengan menggunakan metode Student Team Achievement Divisions (STAD) dan menambahkan penggunaan media audio visual. Pada siklus 2 ini perolehan jumlah nilai keseluruhan 2536 dengan perolehan nilai tertinggi 100 dan nilai terendah adalah 60. Rerata kelas diperoleh nilai 85. Peserta didik yang tuntas dalam belajarnya sebanyak 24 orang dari 30 peserta didik atau $80 \%$ Sedang yang belum tuntas sebanyak 6 orang dari 30 peserta didik atau 20\% Dari hasil pengamatan yang menjawab dengan benar pertanyaan guru sebanyak 24 orang dari 30 peserta didik atau dengan kata lain $80 \%$ dan yang belum menjawab pertanyaan guru dengan benar sebanyak 6 orang dari 30 peserta didik atau $20 \%$.

Pada proses kegiatan pembelajaran siklus 2 ini peserta didik tampak sangat antusias dan termotivasi untuk mengikuti pelajaran IPA. Hal ini di sebabkan karena guru menggunakan media yang digunakan yaitu audio Visual sesuai dengan materi yang telah disiapkan oleh guru. Sehingga selama proses belajar mengajar berlangsung, tercipta suasana 
pembelajaran yang aktif, kreatif, inovatif dan menyenangkan bagi peserta didik.

Dengan demikian penggunaan metode Student Team Achievement Divisions (STAD) dan Media audio Visual dapat meningkakan prestasi belajar peserta didik SDN Anyelis 1 kelas VI Mata Pelajaran Ilmu Pengetahuan Alam (IPA) dengan Tema Ciri - ciri khusus makhluk hidup . Dari hasil pembelajaran pada siklus 2 ini peneliti tidak perlu melakukan perbaikan pembelajaran untuk siklus berikuttnya.

\section{BAB V}

\section{KESIMPULAN DAN SARAN TINDAK LANJUT}

\section{A. Simpulan}

Dari hasil Penelitian Tindakan Kelas (PTK) yang dilakukan dengan melalui beberapa tahapan dan berbagai macam metode pembelajaran serta penggunaan media pembelajaran untuk memperbaiki proses kegiatan belajar yang telah dilaksanakan mulai dari prasiklus, siklus I dan siklus II pada mata pelajaran IPA, maka penulis dapat menarik kesimpulan sebagai berikut :

1. Nilai rata - rata kelas yang diperoleh pada pembelajaran prasiklus adalah 66,2 sedangkan peserta didik yang tuntas dalam belajar hanya mencapai 8 orang dari 30 peserta didik atau $26 \%$ dan yang belum tuntas dalam belajar sebanyak 22 orang dari 30 peserta didik atau 74\% Pada hasil pengamatan diperoleh data bahwa sebanyak 13 orang dari 30 peserta didik atau $43 \%$ dapat menjawab dengan benar sedangkan 17 orang dari 30 peserta didik atau $57 \%$ tidak dapat menjawab dengan benar.. Sedangkan pada pelaksanaan pembelajaran siklus I nilai rata-rata kelas yang diperoleh adalah 71,6. Peserta didik yang berhasil mencapai ketuntasan minimal sebanyak 12 orang dari 30 peserta didik atau $40 \%$ dan peserta didik yang belum mencapai ketuntasan minimal sebanyak 18 orang dari 30 peserta didik atau 60\% Hasil dari pengamatan menunjukkan bahwa sebanyak 14 orang dari 30 peserta didik atau $46 \%$ dapat menjawab dengan benar pertanyaan dari guru sedangkan 16 orang 
dari 30 peserta didik atau 54\% tidak dapat menjawab dengan benar. Melihat hasil yang belum mencapai KKM pada prasiklus dan siklus I peneliti mencoba memperbaiki pembelajaran pada siklus ke II ini, dengan menggunakan metode Student Team Achievement Divisions $(S T A D)$ dan media Audio Visual . Hasilnya pada siklus 2 ini diperoleh Rerata kelas 85 . Peserta didik yang tuntas dalam belajarnya sebanyak 24 orang dari 30 peserta didik atau $80 \%$ sedangkan 6 orang dari 30 peserta didik atau 20\% belum berhasil mencapai ketuntasan minimal. Dan dari hasil pengamatan peserta didik yang dapat menjawab dengan benar pertanyaan guru sebanyak 24 orang dari 30 peserta didik atau $80 \%$, sedangkan 6 orang dari 30 peserta didik atau 20\% belum dapat menjawab pertanyaan guru.

2. Dari hasil yang diperoleh pada pelaksanaan pembelajaran di sikulus II dapat disimpulkan bahwa penerapan metode Student Team Achievement Divisions (STAD) dan penggunaan media Audio Visual dapat memberikan pengaruh yang sangat baik dalam meningkatkan hasil belajar karena memberikan motivasi pada peserta didik dan menciptakan suasana belajar yang aktif, kreatif, inovatif dan menyenangkan.

\section{B. Saran Tindak Lanjut}

Berdasarkan pada kesimpulan diatas ada beberapa hal yang sebaiknya dilakukan guru dalam upaya meningkatkan hasil belajar peserta didik.

1. Guru sebaiknya menyampaikan tujuan pembelajaran sebelum kegiatan belajar mengajar berlangsung dan menyampaikan pula manfaat siswa mempelajari materi pembelajaran agar peserta didik memiliki motivasi yang kuat untuk mempelajari materi tersebut.

2. Guru sebaiknya menciptakan suasana belajar yang aktif, kreatif, inovatif dan menyenangkan di dalam kelas agar peserta didik terlibat langsung secara aktif guna mencapai tujuan pembelajaran yang diharapkan. 
3. Guru sebaiknya menggunakan berbagai macam metode dan media pembelajaran apabila metode yang diterapkan pada pembelajaran sebelumnya belum mencapai tujuan yang diharapkan.

4. Guru sebaiknya memberikan kesempatan seluas-luasnya kepada peserta didik untuk aktif mengeluarkan pendapat, ide dan gagasan dalam proses belajar mengajar agar peserta didik memiliki rasa percaya diri baik di dalam kerja kelompok, diskusi maupun dalam menjawab pertanyaan.

5. Guru sebaiknya selalu berinovasi dalam menerapkan berbagai macam metode dalam proses kegiatan pembelajaran salah satunya adalah penggunaan metode Student Team Achievement Divisions (STAD) dan media audio visual yang dapat memotivasi peserta didik dalam memahami konsep materi pelajaran IPA.

\section{DAFTAR PUSTAKA}

WJS.Purwadarminta.(1986). Kamus Umum Bahasa Indonesia, Jakarta : Balai Pustaka.

Sulfemi, Wahyu Bagja. (2013). Pengaruh Persepsi Siswa atas Kemampuan Pedagogik Guru dan Motivasi Belajar Siswa Terhadap Prestasi Belajar Ilmu Pengetahuan Sosial Siswa (Survei di SMK Swasta Kabupaten Bogor). Edutecno. 7 (2), 17-26.

Mas'ud Khasan Abdul Qohar (1994) Prestasi Belajar dan Kompetensi Guru, Surabaya : Usaha Nasional.

Ngalim Purwanto, (1994) Prestasi Belajar dan Kompetensi Guru, Surabaya : Usaha Nasional.

S. Nasution, (1982) Didaktik Asas-Asas Mengajar, Bandung : Jemmar

Rohman Natawidjaya, (1979), Psikologi Pendidikan untuk SPG, Jakarta : Mutiara

Fajartriani, Tia dan Sulfemi, Wahyu Bagja. (2014). Pengaruh Motivasi Kerja Guru dan Iklim Organisasi Terhadap Kinerja Guru SMA Negeri di Kecamatan Cigudeg. Edutecno. 8 (1), 17-26.

Sulfemi, Wahyu Bagja. (2019). Asosiatif Layanan Tenaga Perpustakaan Sekolah Dengan Motivasi Membaca Siswa di Kabupaten Bogor. Edutecno. 19 (2), 1-10. 
WS. Winkel, (1989), Psikologi Pengajaran, Jakarta : PT. Gramedia

Anitah, S. (2014). Strategi Pembelajaran di SD. Jakarta. Universitas Terbuka

Winataputra, S Udin. (2000). Stategi Belajar Mengajar. Jakarta: Universitas Terbuka.

Abdullah Aly (2009), Ilmu Alamiah dasar. Jakarta : PT. Bumi Aksara

Slavin, robert E (2009) Teori, Riset, Praktik, Bandung : Nusa Media

Sulfemi, W. B. (2015). Pengaruh Metode Pembelajaran Kontekstual dan Penggunaan Media Video Pendidikan Terhadap Hasil Belajar IPS. Edutecno. 13 (2), 1, 10

Sulfemi, Wahyu Bagja dan Lestari, Ayu Hopilatul. (2017). Korelasi Kompetensi Pedagogik Guru dengan Prestasi Belajar Mata Pelajaran IPS Di SMP Muhammadiyah Pamijahan Kabupaten Bogor. Edutecno. $16(1), 1-16$.

Sulfemi, Wahyu Bagja dan Abdul Qodir. (2017). Hubungan Kurikulum 2013 Dengan Motivasi Belajar Peserta Didik Di SMK Pelita Ciampea. Edutecno 17 (2), 1-8

.Sulfemi, Wahyu Bagja dan Nurhasanah. (2018). Penggunaan Metode Demontrasi dan Media Audio Visual Dalam Meningkatkan Hasil Belajar Peserta Didik Mata Pelajaran IPS. Jurnal Pendas Mahakam. 3 (2). 151-158.

Sulfemi, Wahyu Bagja dan Setianingsih. (2018), Penggunaan Tames Games Tournament (TGT) Dengan Media Kartu Dalam Meningkatkan Hasil Belajar. Journal of Komodo Science Education (JKSE. 1 (1), 1-14

Sulfemi, Wahyu Bagja. (2018). Pengaruh Disiplin Ibadah Sholat, Lingkungan Sekolah, dan Intelegensi Terhadap Hasil Belajar Peserta Didik Mata Pelajaran Pendidikan Agama Islam. Edukasi: Jurnal Penelitian Pendidikan Agama dan Keagamaan. 16 (2), 166-178

Sulfemi, Wahyu Bagja dan Desmiati, Zulaicha. (2018). Model Pembelajaran Missouri Mathematics Project Berbantu Media Relief Experience dalam Meningkatkan Hasil Belajar Siswa. Jurnal Pendas Mahakam . 3 (3), 232-245.

Sulfemi, Wahyu Bagja. (2018). Modul Manajemen Pendidikan Non Formal. Bogor: STKIP Muhammadiyah Bogor.

Sulfemi, Wahyu Bagja. (2018). Hubungan Motivasi Belajar Dengan Hasil Belajar IPS Di SMP Kabupaten Bogor. Edutecno 18 (2), 1-8.

Sulfemi, Wahyu Bagja dan Hilga Minati. (2018). Meningkatkan Hasil Belajar Peserta Didik Kelas 3 SD Menggunakan Model Picture And Picture dan Media Gambar Seri. JPSD. 4 (2), 228- 242. 
Sulfemi, Wahyu Bagja dan Supriyadi, Dede. (2018). Pengaruh Kemampuan Pedagogik Guru dengan Hasil Belajar IPS. Edutecno 17 (1), 1-10.

Wardhani, IGAK, (2014), Penelitian Tindakan Kelas, Tangerang Selatan : Universitas Terbuka

Asrori, Muhammad, (2009), Penelitian Tindakan Kelas, Bandung : CV Wacana a

Arikunto, Suharsimi, (2012), Penelitian Tindakan Kelas, Jakarta: Bumi Aksara

Supardi, (2012), Penelitian Tindakan Kelas, Jakarta : Bumi Aksara

Sudirman, Sudirman \& Sulfemi, Wahyu Bagja. (2010). Korelasi Antara Konsep Diri Guru dengan Profesionalisme Guru di SMA Negeri 1 Pamijahan Kabupaten Bogor. Edutecno 2 (2), 10-19

Sugiri, Sugiri \& Sulfemi, Wahyu Bagja. (2011). Pendidikan Multi Kultur di Sekolah Berbasis Keagamaan. Edutecno. 3 (2), 11-20

Yusfiriadi, Yusfiriadi, \& Sulfemi, Wahyu Bagja. (2011). Pemberdayaan Unit Produksi Melalui Pendekatan Manajemen Stratejik di SMK Pertiwi Kabupaten Bogor. Edutecno. 3 (1), 1-10.

Yusfiriadi, Yusfiriadi, \& Sulfemi, Wahyu Bagja. (2012). Penyelewangan Dana Dalam Dunia Pendidikan. Fascho 1 (1), 1-9. 